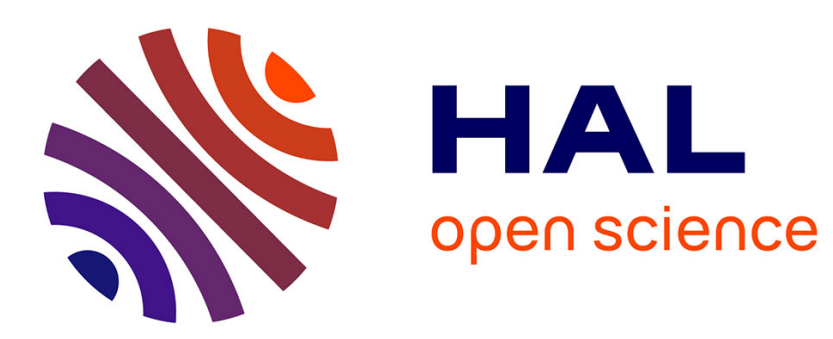

\title{
Interdependence and spillovers: is firm performance affected by others' innovation activities?
}

\author{
Pedro de Faria, Francisco Lima
}

\section{To cite this version:}

Pedro de Faria, Francisco Lima. Interdependence and spillovers: is firm performance affected by others' innovation activities?. Applied Economics, 2011, 44 (36), pp.4765-4775. 10.1080/00036846.2011.560108 . hal-00730231

\section{HAL Id: hal-00730231 \\ https://hal.science/hal-00730231}

Submitted on 8 Sep 2012

HAL is a multi-disciplinary open access archive for the deposit and dissemination of scientific research documents, whether they are published or not. The documents may come from teaching and research institutions in France or abroad, or from public or private research centers.
L'archive ouverte pluridisciplinaire HAL, est destinée au dépôt et à la diffusion de documents scientifiques de niveau recherche, publiés ou non, émanant des établissements d'enseignement et de recherche français ou étrangers, des laboratoires publics ou privés. 


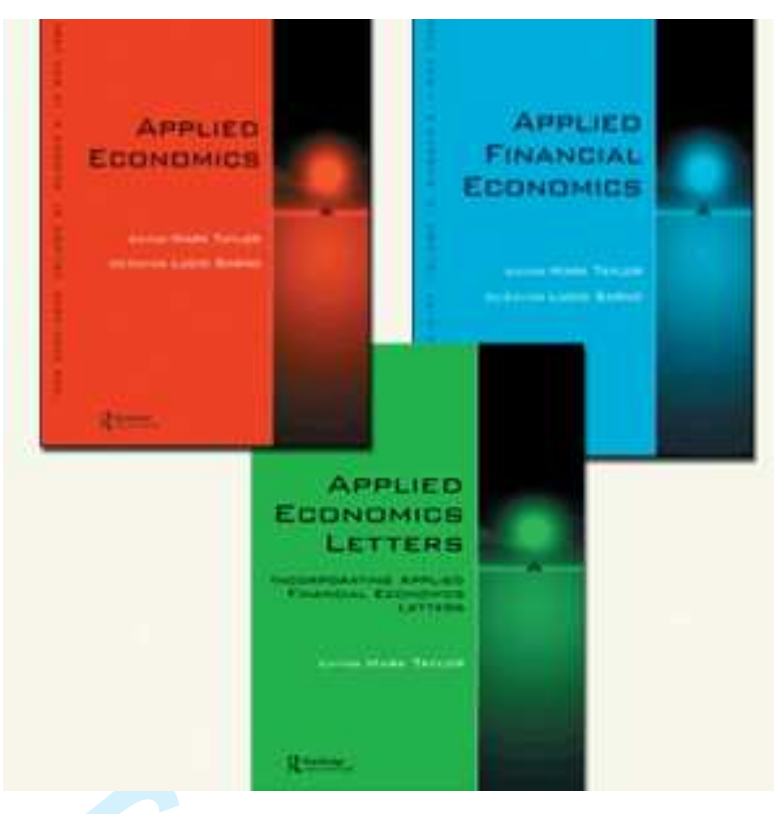

\section{Interdependence and spillovers: is firm performance affected by others' innovation activities?}

\begin{tabular}{|r|l|}
\hline Journal: & Applied Economics \\
\hline Manuscript ID: & APE-2009-0314.R1 \\
\hline Journal Selection: & Applied Economics \\
\hline Author: & 26-Jan-2011 \\
\hline Complete List of Authors: & $\begin{array}{l}\text { de Faria, Pedro; University of Groningen, Department of Innovation } \\
\text { Management and Strategy, Faculty of Economics and Business } \\
\text { Lima, Francisco; Instituto Superior Tecnico, Department of } \\
\text { Engineering and Management; CEG-IST, Centre for Management } \\
\text { Studies }\end{array}$ \\
\hline JEL Code: & $\begin{array}{l}\text { D21 - Firm Behavior < D2 - Production and Organizations < D - } \\
\text { Microeconomics, O31 - Innovation and Invention: Processes and } \\
\text { Incentives < O3 - Technological Change|Research and Development } \\
<\text { O - Economic Development, Technological Change, and Growth, } \\
\text { O32 - Management of Technological Innovation and R\&D < O3 - } \\
\text { Technological Change|Research and Development < O - Economic } \\
\text { Development, Technological Change, and Growth }\end{array}$ \\
\hline Keywords: & $\begin{array}{l}\text { Innovation, Spillovers, Firm performance, Community Innovation } \\
\text { Survey }\end{array}$ \\
\hline &
\end{tabular}




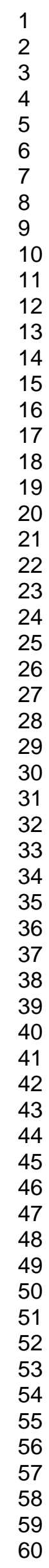

SCHOLARONE ${ }^{m}$
Manuscripts

25

26

27

29

30

31

33

34

35

36

37

38

40

41

42

44

45

46

47

48

49

51

52

53

54

56

57

58

59

60 


\title{
Interdependence and spillovers: is firm performance affected by others' innovation activities?
}

\author{
Pedro de Faria ${ }^{\mathrm{a}}$ and Francisco Lima ${ }^{\mathrm{b}, *}$ \\ ${ }^{a}$ Department of Innovation Management and Strategy, Faculty of Economics and \\ Business, University of Groningen, Nettelbosje 2, 9747 AE Groningen, The \\ Netherlands \\ ${ }^{\mathrm{b}}$ Instituto Superior Técnico, Technical University of Lisbon, and CEG-IST, Av. \\ Rovisco Pais, 1049-001 Lisbon, Portugal
}

*Corresponding author. E-mail: francisco.lima@ist.utl.pt

Running Title: Interdependence and spillovers

\begin{abstract}
The creation of new knowledge is a case in which agents' behaviour can affect the performance of other actors positively, given that new knowledge creates positive externalities in the market. In this context, we investigate the existence of performance spillovers associated with innovation activities by quantifying the innovation produced in surrounding firms and controlling for the fact that a firm is itself an innovation producer. We use data from the Third Community Innovation Survey that measures innovation in a broad way, not reducing it to R\&D and patents, which departs from previous literature on spillovers. Furthermore, to tackle the endogeneity of the innovation variables on the firm production decision, we resort to the firm intellectual property protection methods as an instrument. We found a positive spillover of innovation on firm value added. The results also show that process innovation spillovers are more prevalent than product innovation spillovers.
\end{abstract}




\section{Introduction}

$R \& D$ and innovation have characteristics of public goods, since the investments and results achieved by one agent can produce knowledge that is available, almost freely, to other agents. This process is possible when the reproduction costs for information are low, allowing the diffusion of knowledge to actors who did not invest in its production. As described by Adams and Jaffe (1996), knowledge production processes have two different types of effects: one direct, to the firm enrolled in the knowledge production activity, and one indirect, to other firms that benefit from the public availability of some of the knowledge.

As for the direct effect, it is broadly accepted that $R \& D$ and innovation are essential to firm performance. There is a positive and strong relationship between $\mathrm{R} \& \mathrm{D}$ expenditures and both growth of output and total factor productivity (Griliches, 1986; Hall and Mairesse, 1995). As for the indirect effect, the creation of new knowledge is a case in which agents' behaviour can affect the performance of other actors positively, given that new knowledge creates positive externalities in the market. These externalities are reflected in the positive differences between social and private internal rates of return on R\&D investments (Mansfield et al., 1977). As noted by Nadiri (1993), the social rates of return on R\&D (spillovers) are on average close to $50 \%$, varying considerably across industries. ${ }^{1}$ As stated by Jaffe (1986) and Geroski (1995), the technology developed by innovation projects of one firm is useful to others as well.

\footnotetext{
${ }^{1}$ In industries with well-defined products and strong patents, such as pharmaceuticals, firms are more successful in capturing the research results and the social rates of return are lower.
} 
Despite the fact that this availability of knowledge could be a hampering factor for investment in knowledge production, the existence of these positive externalities - knowledge spillovers - can also generate a feedback mechanism that increases the overall returns on the initial investment in research and innovation and can benefit both producers and non-producers of knowledge. On one hand, spillovers are important for innovative firms, since knowledge production activities are associated with high levels of uncertainty and the existence of a local innovative culture allows agents to share similar experiences and ease the exploitation of new solutions to problems (Feldman, 1993). If a firm masters its absorptive capacity, it can take advantage, not only of its own innovative efforts, but also of others' investment. The right absorptive skills can enable a firm to manage the external information flows in order to maximise the incoming spillovers from other firms and, at the same time, control the spillovers to those firms (Cohen and Levinthal, 1989, 1990). In other words, the production of knowledge by other firms cannot be merely analysed as a process by which competitors increase their knowledge, since innovation activities developed in other firms can produce positive spillovers that are absorbed by firms through several means: publications, reverse engineering, trade of goods, exchange of scientists and collaborations. On the other hand, spillovers are also important to non-innovative firms, because these firms can absorb knowledge through the implementation of incremental modifications on production (products and/or processes). These effects are not usually identified by the firm as innovative efforts or adoption of organizational innovations and therefore are not captured by technological innovation surveys. 
In this context, our analysis seeks to identify the existence of knowledge spillovers that spring from innovation activities and have an impact on the performance of innovative and non-innovative firms. We use data from the Portuguese Third Community Innovation Survey (CIS III) that measures innovation in a broad way, not reducing it to $R \& D$ and patents, which departs from previous literature on spillovers. This perspective allows us to enquire if the existence of non-radical and non-science based innovation activities of firms have an impact on the performance of surrounding firms from the same industry. ${ }^{2}$ Moreover, firm performance is directly measured by value added and not by alternative measures such as turnover.

Since we include variables that measure the innovation performance of firms and the dependent variable is value added, we may face an endogeneity problem. ${ }^{3}$ To tackle this issue, we instrument the innovation variable. The firm engagement in intellectual property protection methods is the instrument used as there is information on this firm decision for both innovative and non-innovative firms.

The results drove us to two main conclusions: the performance of a firm is affected by the fact that other firms innovate and the effect is positive. Firm innovation not only contributes to the performance of the investing firm, but also can produce knowledge that positively affects the performance of other firms. The

\footnotetext{
${ }^{2}$ Surrounding firms meaning: firms belonging to the same industry, in the same region and with similar size (an industry-region-firm size cell).

${ }^{3}$ If better firms (e.g., with higher managerial capabilities) are also the ones investing in innovation, then there is a problem of a correlation between one independent variable - innovation - and the unobserved firm characteristics.
} 
results also show that process innovation spillovers are more prevalent than product innovation spillovers.

The remainder of the study is divided into four sections. Section II develops the hypotheses after building a conceptual framework. Section III describes the data and presents the model specification. In Section IV, the main results are presented and discussed. Finally, Section V concludes and draws some policy implications.

\section{Conceptual Framework}

The innovation capacity of firms and the diffusion, imitation and adoption of innovations have gained increasing importance in the analysis of economic performance of firms, and, in particular, in explaining the differences between the rates of growth of different regions (Solow, 1956; Romer, 1990; Griliches, 1992; Aghion and Howitt, 1992). In particular, the existence of knowledge spillovers is a central concept of the theory of new growth economics (Romer, 1986; Aghion and Howitt, 1992), which stresses the cumulative nature of invention at the industry and geographical level. Romer (1986), Krugman (1991), Grossman and Helpman (1991) and Audretsch and Feldman (1996), amongst others, have focused on the role that spillovers of economic knowledge across agents and firms play in creating increasing returns and economic growth.

Griliches $(1979,1992)$ distinguish two types of $R \& D$ and innovation spillovers, knowledge and rent spillovers. Rent spillovers happen when firms pay less for inputs than the quality of these inputs is worth, more precisely, when quality improvements are not fully reflected in a product's price or if performance 
increases in the production process lower the price of a good. Knowledge spillovers are considered by Griliches (1992) the "true spillovers". They are generated when information and ideas flow from one institution to another institution without payment (Griliches, 1992; De Bondt, 1996). Therefore, they can generate virtuous cycles by attracting additional labour and other inputs, further facilitating the exchange of ideas.

Concerning the type of relationship between the actors involved on the knowledge exchange process, spillovers can be classified as vertical spillovers, when there is costumer/supplier link; horizontal spillovers, when the source of spillovers is a competitor of the receiving firm; and spillovers from universities (Nadiri, 1993; Atallah, 2002; Kaiser, 2002; Arvanitis et al., 2008). In addition, several studies analyse the differences between spillovers that flow from a firm's own industry, intra-industry spillovers and spillovers that occur between firms from different industries, inter-industry spillovers (e.g. Bernstein, 1988; Steurs, 1995; Kaiser, 2002).

Following these works, several empirical analyses of $R \& D$ and productivity have recognised the importance of spillovers. As referred to by Meagher and Rogers (2004), these studies found that spillovers between firms are important in explaining productivity growth by comparing the roles of own research efforts against research efforts of other firms (pool of external knowledge available to a firm).

Spillovers can also be categorized according to the geographical location of the knowledge producer and of the knowledge receiver. The relationship between international and national spillovers are the focus of Harabi (1997), Jaffe and Trajtenberg (1999), Branstetter (2001), Keller (2002) and Negassi (2009), 
while regional or intra-regional spillovers are the subject of several other studies (Arndt and Sternberg, 2000; Acs et al., 2002; Fritsch and Franke, 2004; GumbauAlbert and Maudos, 2009). Audretsch and Feldman (2004) explore the role of geographic proximity in the diffusion of knowledge. They find that spillovers are associated with geographic proximity since tacit knowledge is inherently nonrival in nature. They also state that an increased concentration of a particular industry within a specific geographic region facilitates knowledge spillovers across firms. The best example of this process and its economic importance is the difference in the innovative and economic performance of two different regions of the USA: Silicon Valley and Boston's Route 128. The performance of the California cluster is higher because the proximity and interdependence of the different actors is also higher (Audretsch and Feldman, 2004). In line with this work, Baptista and Swan (1998) and Jaffe et al. (1993) focus their analysis on the clustering process and find that spillovers associated with R\&D activity are geographically localised. The concentration of technologically similar firms can produce several types of economies for firms and attracts additional entrants (Aharonson et al., 2007; Fritsch and Franke, 2004).

The management of spillovers is also a subject of research. Using the Belgium Second Community Innovation Survey (CIS II) database, Cassiman and Veugelers (2002) explore the effects of knowledge flows on R\&D cooperation, focussing on the distinction between incoming spillovers (measured by the importance of publicly available information for the innovation process of the firm) and appropriability. They consider that the ability to absorb incoming spillovers from other firms or institutions is linked to the innovation activities of the firm (own R\&D, for example), participation in cooperative agreements, and 
the technological opportunities in the industry. They find that the level of knowledge of in- and outflows is not exogenous to the firm since firms, through their innovation activities, can model their incoming spillovers and appropriation capabilities. Also using the Community Innovation Survey database, Crespi et al. (2008) analyse, in the UK context, the effect of knowledge flows on the productivity of firms and conclude that most relevant spillovers are associated with competitors and that multinational presence may be an important source of these spillovers.

Our analysis follows the works described above that seek to identify the existence of knowledge spillovers that spring from innovation activities and have an impact on the performance of the firm. More precisely, we will address the following main research question: Is firm performance positively affected by the fact that other firms located in the same region and from the same industry innovate (radically or not)? Our goal is to add new evidence to the knowledge spillovers literature, where nearly every study considers only spillovers associated with R\&D and patenting activities (Bottazzi and Peri, 2003; Chen and Yang, 2005; Aharonson et al., 2007; Alcácer and Chung, 2007). In most regions and industries, $\mathrm{R} \& \mathrm{D}$ and patenting are not activities widely implemented by the majority of firms. So, if we want to study the spillovers that occur in an economy that is not on the technological frontier and where most firms are technology adopters and not radical innovators, we cannot focus our analysis on R\&D and patents.

Following this perspective, we measure innovation in a broader way than the radical innovation or scientific-based innovation, a standpoint that fits 
countries like Portugal. ${ }^{4}$ We will enquire if firms are affected not only by the $\mathrm{R} \& \mathrm{D}$ and radical innovation but also from small product and process innovation increments developed by other firms within the same region and industry. We seek to identify a possible effect of being included in an environment where firms strive to evolve technologically even if not contributing with new knowledge to society.

To attain this goal we use the Portuguese Third Community Innovation Survey (CIS III) database, which provides information on the innovative performance of manufacturing and service firms, as well as their overall performance. Drawing on the information about the innovative behaviour of firms, we built a variable that summarises the innovative performance of firms from the same region, industry and size of a firm. ${ }^{5}$ We consider a production function with value added as the dependent variable and the variable measuring the innovation of other firms as a regressor to measure the indirect effect of innovation on performance of firms of the same industry and region. In this way, we assess regional, inter-industry knowledge spillovers associated to innovation

${ }^{4}$ Portugal has 4.8 patent applications to the EPO per million inhabitants and $0.8 \%$ of GDP dedicated to R\&D (Eurostat, 2007).

${ }^{5}$ We measure spillovers controlling for the factors that Griliches (1992) considered important: relative position in the value chain; technological intensity; and geographic distance. Following

this statement, Kafouros and Buckley (2008) found that, even though all firms benefited (in terms

of productivity) from their own R\&D, only small firms and firms from high tech sectors benefited from the innovation activities undertaken by other firms of the same or other industries. 


\section{Data and Model Specification}

This section describes the data used to address the research questions. In addition, it presents the model specification and the methodological issues associated with

it.

Data

activities. By incorporating a measure of "borrowed" innovation into a production function, and following the influential work of Griliches (1979), which first added data on $R \& D$ to the list of inputs entering the production function, we verify whether spillovers play an important role in enhancing firm performance.

Testing if the knowledge produced by firms' innovation activities spills over to other firms requires micro-level data with matching firm-level information on innovation and production. This information can be found in the Portuguese Community Innovation Survey (CIS) database. The CIS, executed under the supervision of the European Community (EU), is focused on the observation and collection of quantitative data on technological innovation. The sample is representative of the population of the manufacturing sector and also of five selected service sectors (and only firms with more than 10 employees were considered). The usual consistency and logical tests, as well as corrections for possible bias associated with non-responses, were performed for each country at the firm level. 
Developed under the guiding principles of the Oslo Innovation Manual (OECD, 1992), the survey aims at collecting data on innovation understood from a broad firm perspective, rather than examining just the invention process. Thus, the CIS captures a larger variety of innovation activities than just R\&D expenditures, including the acquisition of patents and licenses, product design, personnel training, trial production and market analysis. Moreover, it includes measures of innovative output not reflected in the submission of patent filings, including the introduction of innovative production processes and organizational changes. The importance of the CIS data is attested by a number of recent works that draw on this survey. Results obtained by Cassiman and Veugelers (2002) and Mohnen and Dagenais (2002) are good examples of the growing use of the CIS data to further our understanding of innovation at the micro level. ${ }^{6}$

The survey enquires if firms have introduced at least one innovation in the period from 1998 to 2000. Specifically, the innovation question is asked as a binary query: has your firm incorporated any innovation in the last three years? This query was complemented by a validation question, which asked firms to describe the innovations. If the answer to this question was no, it asked if the firm had tried to innovate. To the firm that either introduced or attempted to introduce an innovation, a number of questions associated with the innovation process followed. The survey also collects information on the expenditures on innovation activities, such as intramural and extramural $\mathrm{R} \& \mathrm{D}$, acquisition of machinery or

\footnotetext{
${ }^{6}$ Smith et al. (2004) and Negassi (2009) are also recent studies using CIS data. These papers also show the capabilities of the survey when CIS data is merged with other data sources and where the longitudinal dimension is available and explored.
} 
other external knowledge, training, market introduction of innovation, design or other types of preparations for the production or distribution of innovation.

These two variables - engagement in innovation activities and expenditures in innovation - are the critical indicators of innovative activity considered in this paper. Using these variables provides a number of advantages. Firstly, we look at innovation in a broad sense, not only at the adoption of a specific technological innovation (such as computers). Secondly, it provides information about innovations beyond that linked to patent applications. As mentioned above, this helps to understand the innovation process in countries where patents are not common, or that are far from the technological frontier, such as Portugal. Finally, we can investigate differences between product and process innovation, in order to enquire if demand enhancing and cost reducing innovations have different effects on firms' performance, as stated in several studies (Leiponen, 2000; Rouvinen, 2002).

Table 1 presents the mean and standard deviation of the variables used in this study. The survey provides data on firm's value added, capital, number of employees and their schooling levels, if the firm belongs to a national or multinational group, the exports weight on turnover and the above measures of innovation activities. ${ }^{7}$ As can be seen from Table $1,44 \%$ of the firms that answered the survey reported some kind of innovation activities. The innovation activities can be separated between process and product innovation, $30 \%$ and $35 \%$

\footnotetext{
${ }^{7}$ The survey does not provide information on the book values of capital stock for equipment and structures. Therefore, we had to resort to the closest variables available: the value of gross investment in tangible goods and an indicator of capital use calculated by the difference between turnover and value added. We assume that the sum of these two variables reflects the relative levels of capital stock employed by firms.
} 
respectively. Concerning the workforce structure, on average, employees with higher education are a minority in this sample. In addition, there is a higher variance in the number of employees with higher education than in the number of employees without this level of education, given an indication that there are significant differences between firms regarding absorptive capacity. Finally, only $19 \%$ and $11 \%$ of the firms are part of a national and multinational group, respectively; only $37 \%$ export more than ten percent of their turnover; and the majority are not engaged in any intellectual property protection method (69\%).

\section{(Insert Table 1)}

\section{Model}

We consider a production function model to analyse the existence of knowledge spillovers associated with innovation activities. We quantify the innovation produced in surrounding firms by the percentage of innovative firms across industry, sector and size and control for the fact that a firm itself can be an innovation producer. We assume a value-added Cobb-Douglas production function for firm $i$ with the following specification: ${ }^{8}$

$$
Y_{i}=A_{i} L_{H i}^{\beta_{1}} L_{N H i}^{\beta_{2}} K_{i}^{\beta_{3}} e^{u_{i}}
$$

\footnotetext{
${ }^{8}$ Value added is used instead of productivity (value added per worker) because the use of productivity implies a restriction of the coefficients and constant returns to scale. The variable value added is specific to the Portuguese CIS.
} 
where $L_{H}$ and $L_{N H}$ are the number of employees with higher education (college or higher) and without higher education, respectively, in order to control for the qualifications of the workforce and measure the absorptive capacity of the firm; $K$ is capital; and $u$ is a stochastic disturbance. The total factor productivity parameter (A) is assumed to be driven by exports, inclusion in a group (national or multinational), industry and region characteristics, and the innovation activities of the firm and surrounding firms. We define $A$ as

$$
A_{i}=\exp \left(\theta_{1} I_{i}+\theta_{2} S_{i}+\sum_{k} \delta_{k} D_{k}+\sum_{h} \lambda_{h} R_{h}+\sum_{j} \gamma_{j} G_{j}\right)
$$

where $I$ and $S$ are indicators of innovation activities of the firm and the surrounding firms, respectively. The industry $(D)$ and region $(R)$ dummies capture differences in market and technological opportunities across industries and regions. The dummies for differences in internal organization and firm performance $(G)$ are defined as firm belonging to a national group and/or a multinational group, and firm exports are higher than $10 \%$ of its turnover. Taking logarithms, the production function becomes,

$$
y_{i}=\beta_{0}+\beta_{1} l_{H i}+\beta_{2} l_{N H i}+\beta_{3} k_{i}+\theta_{1} I_{i}+\theta_{2} S_{i}+\sum_{k} \delta_{k} D_{k}+\sum_{h} \lambda_{h} R_{h}+\sum_{j} \gamma_{j} G_{j}+u_{i}
$$

where the lowercase letters denote logs.

Two variables were used to measure the firm own innovation: a dummy variable indicating if a firm is engaged in innovation activities; and the logarithm of expenditures in innovation activities. We defined three different variables to 
capture the effect of innovative performance of surrounding firms - the spillover measured across industry, sector and firm size: percentage of innovative firms; percentage of product innovative firms; and percentage of process innovative firms. ${ }^{9}$ Our choice of defining these variables restricting by location, sector and size is based on the assumption, described by Griliches (1992) and more recently by Aharonson et al. (2007), that firms can more easily capture spillovers from firms located in the same region, sector and with a similar dimension. The distinction between process and product spillovers is founded in the idea that, although both can contribute to an increase in the output of the firm, the magnitude and pervasiveness of spillovers for product and process R\&D are likely to be different (Ornaghi, 2006). ${ }^{10}$

We only consider knowledge produced in the region where the firm is located since there is evidence that non-codified knowledge attached to people and firms does not diffuse for actors located more than $300 \mathrm{~km}$ away from the knowledge source (Kaufmann and Tödtling, 2002; Botazzi and Peri, 2003; Aldieri and Cincera, 2008). ${ }^{11}$. The path dependence of most of the technological

\footnotetext{
${ }^{9}$ Industry measured by NACE sections (two digits corresponding to seven industries); region by NUTS 2 level (five regions); and size was controlled by dividing firms into two groups: small (fewer than 50 employees) and medium / large firms (more than 50 employees). These three dimensions define a space with 70 cells.

${ }^{10}$ Several studies are focused on the spillovers associated with $R \& D$ activities, a measure of the innovative input. Our study uses measures of innovation output - engagement in innovation activities and expenditures on innovation activities - that, in our opinion, give a more trustful assessment of the real impact of innovation on the performance of firms.

${ }^{11}$ Despite the fact that Portugal is a relatively small country, the structural economic disparities between regions and the existence of several regional clusters explain option to consider only regional spillovers. There are considerable regional disparities in levels of entrepreneurial and
} 
knowledge and of its market applications makes the significance of potential spillovers stronger within rather than across sectors, since, in order to take advantage of spillovers, firms have to share a technological knowledge base. As stated by Griliches (1992), external knowledge is more valuable if it comes from a player within the same industry. Cohen and Levinthal (1990) and Lane and Lubatkin (1998) also argue that firms have a higher probability of absorb knowledge from similar partners and in areas where a firm has knowledge and experience. Acs et al. (1994) state that small and large firms have different innovation production functions. Furthermore, Aharonson et al. (2007) assert that small firms are more likely to capture knowledge from firms of the same dimension and located in the same region.

The inclusion of firm innovation amongst the determinants of productivity raises a possible endogeneity problem as this variable is potentially correlated with the error term in Equation 3. ${ }^{12}$ In this context, using ordinary least squares (OLS) does not guarantee the consistency of the estimators. The solution adopted was to implement an instrumental variable (IV) approach. ${ }^{13}$ The success of this

innovation activities amongst Portuguese regions, with a high concentration of firms along the coastline. Knowledge based activities are mainly concentrated in a few key regions, namely Lisbon, Oporto, Aveiro, Faro, and surrounding areas, corresponding to the largest urban agglomerations. Inland regions display relatively low densities of knowledge based economic activities.

${ }^{12}$ Moreover, the sample probably has a higher incidence of innovative firms given that the survey had explicitly the objective of measuring innovation activities.

${ }^{13}$ As stressed by Angrist and Krueger (2001), using a linear regression for the first-stage estimates generates consistent second-stage estimates even with a dummy or censored endogenous variable (which are the cases of our innovation indicators). Wooldridge (2002) corroborates this statement 
estimation depends on finding effective instruments that lead to the correct identification of all model parameters. The instrument chosen was a dummy variable that identifies if firms are engaged in any intellectual property protection method: registration of design, trademarks, patents, confidentiality agreements, copyright, secrecy, complexity of design and lead-time advantage on competitors. This variable is correlated to the innovative performance even after partialing out all the explanatory variables, and there is no apparent reason to be correlated with unobserved heterogeneity in Equation 3.

\section{Results and Discussion}

The estimation results from the production function model are presented and discussed in this section. The objective is to have a representation of the production decision of the firm. With that end, we consider the resources used by the firm - measures of labour and capital - and a set of other factors affecting the total factor productivity as determinants of the value-added. The firm innovation activities and the possible spillovers occurring from the innovation activities of other firms are among these determinants. The spillovers are measured by the percentage of firms engaged in innovation activities in each cell defined by industry, region and firm size. In this way, we place a firm among similar firms and capture if their innovation activities have any effect on its performance. We report the results in the following tables with the OLS and IV estimates. Table 2 shows the results of the specifications where the innovation variable was

stressing that discrete and endogenous variables can be used in instrumental variables, without any additional assumptions. 
(Insert Table 3)

(Insert Table 2)

All tables report three different specifications of the model estimated by OLS and IV: the first includes capital, human capital, innovation, spillover variables, the industry and region dummy variables and the controls for being part of a group and for international exposure; the second and third specifications are similar to the first specification differing only in the spillover variable: the second includes the product innovation variable and the third the process innovation variable. $^{14}$

The estimation results do not vary substantially across specifications. Furthermore, it does not make a difference for the effect of the remaining variables whether innovation is included as a dummy or as expenditures. The comparison between the OLS and IV estimations shows that the differences are substantial at the values obtained for the estimated coefficients on innovation. The

\footnotetext{
14 As most innovative firms report product and process innovations, the two indicators of innovation activities (product and process) are highly collinear. The solution was to run two separate specifications.
} 
effect of innovation dummy increases from 0.198 in the OLS estimation (specification (1) in Table 2) to 0.523 in the IV estimation (specification (4) in Table 2). The corresponding effects of the innovation expenditures are 0.041 and 0.109 , respectively in specification (1) and (4) of Table 2. The positive and significant effect of the spillover - the percentage of surrounding firms with innovation activities - is maintained with the IV method. ${ }^{15}$

The main result that should be highlighted is that the variables measuring innovation and spillovers are significant and positively partially correlated with value added. It means that value added is affected by innovation activities in two different ways: not only when the innovation is developed by the firm, but also when the firm is located within an innovative environment. The difference between process innovation and product innovation spillovers, despite being small, is also observed in the two tables. Firms capture more knowledge from process innovation than from product innovation. A possible explanation for this finding is that process innovations are more easily implemented by firms and have a deeper impact on the performance of firms

As expected, the coefficients on capital and labour are significant and positive. In addition to the expected link between firm performance and size, from this finding we can infer that the qualification of the human resources is also a determinant of the value added. The fact that the coefficient of the variable employees without higher education is higher than the coefficient of the variable

\footnotetext{
${ }^{15}$ Note that the chosen instrument - dummy for engagement in intellectual property protection proved to be a strong instrument, as its estimation coefficient has the expected sign (positive) and was significant at the $1 \%$ level in the linear projection of innovation (dummy or expenditures) onto all the exogenous variables. Moreover, the partial R-squared was $8 \%$.
} 


\section{Conclusions}

This paper contains several contributions to the literature on innovation spillovers. We use a more precise measure of firm performance by resorting to the value added of each firm, instead of using an indirect measure like the firm total revenue. In addition, the innovation variable comprises a broader definition than the usual stricter one. We do not confine our analysis to R\&D-based innovations or patents, since we have information that includes incremental innovation activities. Furthermore, we found a suitable instrument for innovation to solve the 
endogeneity on the firm production function: the firm engagement in intellectual property protection methods.

A main conclusion can be drawn from the findings: innovation activity has a direct and an indirect impact on firm performance. We found evidence on the existence of a knowledge spillover in the context of the firm production. It provides a clear answer to our main research question: the performance of a firm is affected by the fact that other firms innovate and this effect is positive. Another feature that is visible in this analysis is the role of the workforce qualification: firms with more employees with higher education have a better performance and are more able to absorb knowledge spillovers.

Using firm level data on innovation that cover not only radical and patentable innovation, but also incremental and firm level innovations, this study contributes to the understanding of innovation at the level below the technological frontier. Most of the Portuguese economy is far from this frontier and it is relevant to study how firms absorb new knowledge that, despite not being new to the economy, is new to its context.

Therefore, policy implications can be drawn from our findings. Public policies directly aimed at promoting firm performance should support firm level innovation activities since innovation investments not only have a positive effect on performance but also can have a reproductive effect on others firms' performance. In addition, and in line with our finding that process and product innovation activities have different effects on firm performance, policies should take into attention the different nature of these innovation activities.

At the regional level, policy makers must take into account possible positive effects of these activities on the performance of other firms when 
promoting local development through innovation activities. Policies aimed at fostering economic development at the regional level should stimulate synergies between firms, in order to maximise the rates on return of innovation investments. Examples of such policies are the creation of technology and industrial parks, where the proximity between firms is supported by an integrated management of common infrastructures; or, when deciding on incentives to direct foreign investment, the government has to take into account the possible knowledge spillovers, in addition to the effects on the employment creation or direct technology transfers between firms. In the Portuguese context, these are very important results, given that they stress the role of two priority issues for the country: education and institutional trust - an essential condition for the creation of cooperation arrangements that facilitate knowledge creation and spillovers.

\section{Acknowledgments}

The authors would like to thank Marco Vivarelli, Maria do Rosário Martins, Tobias Schmidt, Wolfgang Sofka and the participants of the European Regional Science Association (ERSA) 47th Congress, DRUID-DIME Academy Winter $2008 \mathrm{PhD}$ Conference, and 2008 Technology, Management and Policy Graduate Consortium Annual Meeting for their valuable comments. The research reported in this paper was partially supported by Gabinete de Planeamento, Estratégia, Avaliação e Relações Internacionais (GPEARI) [Statistical Office of the Ministry for Science and Higher Education, Portugal], by the project PTDC/ESC/67665/2006 of the Portuguese Foundation for Science and Technology (FCT) and by the COINVEST project, www.coinvest.org.uk, funded by the European Commission Seventh Framework Programme, Theme 9, Socio- 
economic Science and Humanities, grant number 217512. The authors are grateful to the Portuguese Foundation for Science and Technology (FCT) - POS_C Programme - for its financial support. Substantial parts of this research were conducted while Pedro de Faria was at IN+ Center for Innovation, Technology and Policy Research, Instituto Superior Técnico, Portugal.

\section{References}

Acs, Z., Audretsch, D. and Feldman, M. (1994) R\&D spillovers and recipient firm size, Review of Economics and Statistics, 76, 336-40.

Acs, Z., Anselin, L. and Varga, A. (2002) Patents and innovation counts as measures of regional production of new knowledge, Research Policy, 31, 1069-85.

Adams, J. and Jaffe, A. (1996) Bounding the effects of R\&D: an investigation using matched establishment-firm data, The RAND Journal of Economics, 27, 700-21.

Aghion, P. and Howitt, P. (1992) A model of growth through creative destruction, Econometrica, 60, 323-51.

Aharonson, B., Baum, J. and Feldman, M. (2007) Desperately seeking spillovers? Increasing returns, industrial organization and the location of new entrants in geographic and technological space, Industrial and Corporate Change, 16, 89-130.

Alcácer, J. and Chung, W. (2007) Location strategies and knowledge spillovers, Management Science, 53, 760-76. 
Aldieri, L. and Cincera, M. (2009) Geographic and technological R\&D spillovers within the triad: Micro evidence from US patents, Journal of Technology Transfer, 34, 196-211.

Angrist, J. and Krueger, A. (2001) Instrumental variables and the search for identification: From supply and demand to natural experiments, Journal of Economic Perspectives, 15, 69-85.

Arndt, O. and Sternberg, R. (2000) Do manufacturing firms profit from intraregional innovation linkages? An empirical based answer, European Planning Studies, 8, 465-85.

Arvanitis, S., Sydow, N. and Woerter, M. (2008) Is there any impact of university-industry knowledge transfer on innovation and productivity? An empirical analysis based on Swiss firm data, Review of Industrial Organization, 32, 77-94.

Atallah, G. (2002) Vertical R\&D spillovers, cooperation, market structure, and innovation, Economics of Innovation and New Technology, 11, 179-209.

Audretsch, D. and Feldman, M. (1996) R\&D spillovers and the geography of innovation and production, American Economic Review, 86, 253-73.

Audretsch, D. and Feldman, M. (2004) Knowledge spillovers and the geography of innovation, in Handbook of Regional and Urban Economics (vol. 4) (Ed.) V. Henderson and J. Thisse, Elsevier, Amsterdam, pp. 2713-39.

Baptista, R. and Swann, P. (1998) Do firms in clusters innovate more?, Research Policy, 27, 525-40.

Bernstein, J. (1988) Costs of production, intra- and inter-industry R\&D spillovers: Canadian evidence, Canadian Journal of Economics, 21, 324-47. 
Bottazzi, L. and Peri, G. (2003) Innovation and spillovers in regions: Evidence from European patent data, European Economic Review, 47, 687-710.

Branstetter, L. (2001) Are knowledge spillovers international or intranational in scope?, Journal of International Economics, 53, 53-80.

Cassiman, B. and Veugelers, R. (2002) R\&D cooperation and spillovers: Some empirical evidence from Belgium, American Economic Review, 92, 116984.

Chen, J.-R. and Yang, C.-H. (2005) Technological knowledge, spillover and productivity: evidence from Taiwanese firm level panel data, Applied Economics, 37, 2361-71.

Cohen, W. and Levinthal, D. (1989) Innovation and learning: The two faces of R\&D, The Economic Journal, 99, 569-96.

Cohen, W. and Levinthal, D. (1990) Absorptive capacity: A new perspective on learning and innovation, Administrative Science Quarterly, 35, 128-52.

Crespi, G., Criscuolo, C., Haskel, J. and Slaughter, M. (2008) Productivity growth, knowledge flows and spillovers, NBER Working Paper No. 13959.

De Bondt, R. (1996) Spillovers and innovation activities, International Journal of Industrial Organization, 15, 1-28.

Eurostat (2007) Europe in figures - Eurostat yearbook 2006-07, Eurostat, Luxembourg :

Feldman M. (1993) An examination of the geography of the innovation, Industrial and Corporate Change, 2, 451-70.

Fritsch, M. and Franke, G. (2004) Innovation, regional knowledge spillovers and R\&D cooperation, Research Policy, 33, 245-55. 
Geroski, P. (1995) Markets for technology: Knowledge, innovation, and appropriability, Handbook of the Economics of Innovation and Technological Change (Ed.) P. Stoneman, Blackwell, Oxford, pp. 90-131.

Griliches Z. (1979) Issues in assessing the contribution of research and development to productivity growth, Bell Journal of Economics, 10, 92116.

Griliches, Z. (1986) Productivity, R\&D, and basic research at the firm level in the 1970s, American Economic Review, 76, 141-54.

Griliches, Z. (1992) The search for R\&D spillovers, Scandinavian Journal of Economics, 94, 29-47.

Grossman, G. and Helpman, E. (1991) Innovation and growth in the global economy, MIT Press, Cambridge, MA.

Gumbau-Albert, M. and Maudos, J. (2009) Patents, technological inputs and spillovers among regions, Applied Economics, 41, 1473-86.

Hall, B. and Mairesse, J. (1995) Exploring the relationship between R\&D and productivity in French manufacturing firms, Journal of Econometrics, 65, 263-93.

Harabi, N. (1997) Channels of R\&D spillovers: An empirical investigation of Swiss firms, Technovation, 17, 627-35.

Jaffe, A. (1986) Technological opportunity and spillovers of R\&D, American Economic Review, 76, 984-1001.

Jaffe, A. and Trajtenberg, M. (1999) International knowledge flows: Evidence from patent citations, Economics of Innovation and New Technology, 8, $105-37$. 
Jaffe, A., Trajtenberg, M. and Henderson, R. (1993) Geographic localization of knowledge spillovers as evidenced by patent citations, Quarterly Journal of Economics, 63, 577-98.

Kafouros, M. and Buckley, P. (2008) Under what conditions do firms benefit from the research efforts of other organizations?, Research Policy, 37, 225-39.

Kaiser, U. (2002) Measuring knowledge spillovers in manufacturing and services: An empirical assessment of alternative approaches, Research Policy, 31, $125-44$.

Kaufmann, A. and Tödtling, F. (2002) How effective is innovation support for SMEs? An analysis of the region of Upper Austria, Technovation, 22, 14759.

Keller, W. (2002) Geographical localization of international technology diffusion, American Economic Review, 92, 120-40.

Krugman, P. (1991) Geography and Trade, MIT Press, Cambridge, MA.

Lane, P. and Lubatkin, M. (1998) Relative absorptive capacity and interorganizational learning?, Strategic Management Journal, 19, 461-77.

Leiponen, A. (2000) Competencies, innovation and profitability of firms, Economics of Innovation and New Technology, 9, 1-24.

Mansfield, E., Rapoport, J., Romeo, A., Wagner, S. and Beardsley, G. (1977) Social and private rates of return from industrial innovations, Quarterly Journal of Economics, 91, 221-40.

Meagher, K. and Rogers, M. (2004) Network density and R\&D spillovers, Journal of Economic Behavior and Organization, 53, 237-60.

Mohnen, P. and Dagenais, M. (2002) Towards an innovation intensity index: the case of CIS 1 in Denmark and Ireland, in Innovation and Firm 
Performance: Econometric Explorations of Survey Data (Ed.) A.

Kleinknecht and P. Mohnen, Palgrave, Hampshire and New York, pp. 3-30.

Nadiri, M. (1993) Innovations and technological spillovers, NBER Working Paper No. 4423.

Negassi, S. (2009) International R\& D spillovers and economic performance of firms: an empirical study using random coefficient models, Applied Economics, 41, 947-76.

OECD (1992) Proposed guidelines for collecting and interpreting technology innovation data - Oslo manual, OECD, Paris.

Ornaghi, C. (2006) Spillovers in product and process innovation: Evidence from manufacturing firms, International Journal of Industrial Organization, 24, $349-80$.

Romer, P. (1986) Increasing returns and long run growth, Journal of Political Economy, 94, 1002-37.

Romer, P. (1990) Endogenous technological change, Journal of Political Economy, 98, S71-S102.

Rouvinen, P. (2002) Characteristics of product and process innovators: Some evidence from the Finnish innovation survey, Applied Economics Letters, 9, $575-80$.

Smith, V., Dilling-Hansen, M., Eriksson, T. and Madsenand, E. S. (2004) R\&D and productivity in Danish firms: some empirical evidence, Applied Economics, 36, 1797-806.

Solow, R. (1956) A contribution to the theory of economic growth, Quarterly Journal of Economics, 70, 65-94. 
Steurs, G. (1995) Inter-industry R\&D spillovers: What difference do they make?, International Journal of Industrial Organization, 13, 249-76.

Wooldridge, J. (2002) Econometric analysis of cross section and panel data, MIT Press, Cambridge, MA. 
Table 1. Descriptive statistics

\begin{tabular}{|c|c|c|}
\hline Variable & Mean & Std. Dev. \\
\hline Value Added $(\log )$ & 6.69 & 2.24 \\
\hline Engagement in innovation activities (dummy) & 0.44 & 0.50 \\
\hline Expenditures in innovation activities (log) & 2.13 & 2.76 \\
\hline Capital (log) & 7.81 & 1.89 \\
\hline No. of employees with higher education $(\log )$ & 1.18 & 1.40 \\
\hline No. of employees without higher education (log) & 3.89 & 1.27 \\
\hline Part of a National Group (dummy) & 0.19 & 0.39 \\
\hline Part of a Multinational Group (dummy) & 0.11 & 0.31 \\
\hline Exports Dummy (> 10\%) & 0.37 & 0.48 \\
\hline$\%$ innovative firms by industry, region and size & 43.89 & 17.09 \\
\hline$\%$ product innovative firms by industry, region and size & 29.81 & 14.02 \\
\hline$\%$ process innovative firms by industry, region and size & 34.03 & 16.09 \\
\hline Engagement in any intellectual property protection method & 0.31 & 0.46 \\
\hline
\end{tabular}


Table 2. Production function OLS and IV estimations with engagement in innovation activities as innovation variable

\begin{tabular}{lllllll}
\hline & $(1)$ & $(2)$ & $(3)$ & $(4)$ & $(5)$ & $(6)$ \\
\hline & OLS & & & IV & & \\
Engagement in innovation & $0.198^{* *}$ & $0.212^{* *}$ & $0.206^{* *}$ & $0.523^{*}$ & $0.528^{*}$ & $0.520^{*}$ \\
activities (dummy) & $(0.099)$ & $(0.099)$ & $(0.098)$ & $(0.306)$ & $(0.306)$ & $(0.306)$ \\
& $0.175^{* * *}$ & $0.177^{* * *}$ & $0.177^{* * *}$ & $0.160^{* * *}$ & $0.161^{* * *}$ & $0.162^{* * *}$ \\
Capital (log) & $(0.051)$ & $(0.050)$ & $(0.051)$ & $(0.053)$ & $(0.052)$ & $(0.053)$ \\
& $0.256^{* * *}$ & $0.257^{* * *}$ & $0.253^{* * *}$ & $0.234^{* * *}$ & $0.236^{* * *}$ & $0.232^{* * *}$ \\
No. of employees with & $(0.062)$ & $(0.063)$ & $(0.063)$ & $(0.064)$ & $(0.065)$ & $(0.064)$ \\
higher education (log) & $0.543^{* * *}$ & $0.563^{* * *}$ & $0.548^{* * *}$ & $0.552^{* * *}$ & $0.569^{* * *}$ & $0.554^{* * *}$ \\
No. of employees without & $(0.084)$ & $(0.087)$ & $(0.080)$ & $(0.084)$ & $(0.087)$ & $(0.080)$ \\
higher education (log) & $0.309^{* *}$ & $0.310^{* *}$ & $0.312^{* *}$ & $0.300^{* * *}$ & $0.301^{* *}$ & $0.303^{* *}$ \\
Part of a National Group & $(0.128)$ & $(0.128)$ & $(0.128)$ & $(0.126)$ & $(0.127)$ & $(0.126)$ \\
(dummy) & $0.373^{* *}$ & $0.371^{* *}$ & $0.372^{* *}$ & $0.404^{* *}$ & $0.401^{* *}$ & $0.402^{* *}$ \\
Part of a Multinational & $(0.158)$ & $(0.158)$ & $(0.158)$ & $(0.159)$ & $(0.159)$ & $(0.159)$ \\
Group (dummy) & 0.142 & 0.154 & 0.150 & 0.152 & 0.162 & 0.158 \\
Exports Dummy (> 10\%) & $(0.102)$ & $(0.102)$ & $(0.102)$ & $(0.101)$ & $(0.101)$ & $(0.101)$ \\
\% innovative firms by & $0.012^{* * *}$ & & & $0.010^{* *}$ & & \\
industry, region and size & $(0.004)$ & & & $(0.005)$ & & \\
\% product innovative firms & & $0.010^{*}$ & & & 0.009 & \\
by industry, region and size & & $(0.006)$ & & & $(0.006)$ & \\
\% process innovative firms & & & $0.012^{* * *}$ & & & $0.010^{* *}$ \\
by industry, region and size & & & $(0.004)$ & & & $(0.005)$ \\
Industry Dummies & Yes & Yes & Yes & Yes & Yes & Yes \\
Region Dummies & Yes & Yes & Yes & Yes & Yes & Yes \\
\hline Observations & 1396 & 1396 & 1396 & 1396 & 1396 & 1396 \\
Adjusted R-squared & 0.48 & 0.48 & 0.48 & 0.47 & 0.47 & 0.47 \\
F-statistic & 56.94 & 56.88 & 56.83 & 57.36 & 57.31 & 57.22 \\
\hline Notes Robus stangrd & & & & & & \\
\hline
\end{tabular}

Notes: Robust standard errors in parentheses. The dependent variable is the firm's value added $(\log )$.

* significant at $10 \%$; ** significant at $5 \%$; *** significant at $1 \%$. 
Table 3. Production function OLS and IV estimations with expenditures in innovation activities as innovation variable

\begin{tabular}{|c|c|c|c|c|c|c|}
\hline & 1) & (2) & (3) & (4) & (5) & (6) \\
\hline & \multicolumn{3}{|c|}{ OLS } & \multicolumn{3}{|c|}{ IV } \\
\hline \multirow{2}{*}{$\begin{array}{l}\text { Expenditures in innovation } \\
\text { activities }(\log )\end{array}$} & $0.041 * *$ & $0.043^{* *}$ & $0.043^{* *}$ & $0.109^{*}$ & $0.110^{*}$ & $0.108^{*}$ \\
\hline & $(0.021)$ & $(0.021)$ & $(0.021)$ & $(0.064)$ & $(0.063)$ & $(0.063)$ \\
\hline \multirow[t]{2}{*}{ Capital (log) } & $0.171 * * *$ & $0.172 * * *$ & $0.172 * * *$ & $0.148^{* * *}$ & $0.149 * * *$ & $0.150 * * *$ \\
\hline & $(0.050)$ & $(0.050)$ & $(0.051)$ & $(0.055)$ & $(0.055)$ & $(0.056)$ \\
\hline \multirow{2}{*}{$\begin{array}{l}\text { No. of employees with } \\
\text { higher education (log) }\end{array}$} & $0.246 * * *$ & $0.248 * * *$ & $0.243 * * *$ & $0.209 * * *$ & $0.211 * * *$ & $0.207 * * *$ \\
\hline & $(0.065)$ & $(0.065)$ & $(0.065)$ & $(0.071)$ & $(0.071)$ & $(0.071)$ \\
\hline \multirow{2}{*}{$\begin{array}{l}\text { No. of employees without } \\
\text { higher education (log) }\end{array}$} & $0.531 * * *$ & $0.550 * * *$ & $0.534 * * *$ & $0.518 * * *$ & $0.536 * * *$ & $0.519 * * *$ \\
\hline & $(0.082)$ & $(0.085)$ & $(0.079)$ & $(0.083)$ & $(0.086)$ & $(0.080)$ \\
\hline \multirow{2}{*}{$\begin{array}{l}\text { Part of a National Group } \\
\text { (dummy) }\end{array}$} & $0.306^{* *}$ & $0.307^{* *}$ & $0.309^{* *}$ & $0.292 * *$ & $0.292 * *$ & $0.295^{* *}$ \\
\hline & $(0.128)$ & $(0.128)$ & $(0.128)$ & $(0.125)$ & $(0.126)$ & $(0.125)$ \\
\hline \multirow{2}{*}{$\begin{array}{l}\text { Part of a Multinational } \\
\text { Group (dummy) }\end{array}$} & $0.382^{* *}$ & $0.379^{* *}$ & $0.381^{* *}$ & $0.426 * * *$ & $0.423 * * *$ & $0.424 * * *$ \\
\hline & $(0.158)$ & $(0.158)$ & $(0.158)$ & $(0.163)$ & $(0.163)$ & $(0.163)$ \\
\hline \multirow[t]{2}{*}{ Exports Dummy (> 10\%) } & 0.145 & 0.157 & 0.153 & 0.161 & $0.171 *$ & $0.166^{*}$ \\
\hline & $(0.101)$ & $(0.101)$ & $(0.101)$ & $(0.101)$ & $(0.101)$ & $(0.101)$ \\
\hline \multirow{2}{*}{$\begin{array}{l}\% \text { innovative firms by } \\
\text { industry, region and size }\end{array}$} & $0.012 *$ & & & $0.011 * *$ & & \\
\hline & $(0.00$ & & & $(0.004)$ & & \\
\hline \multirow{2}{*}{$\begin{array}{l}\% \text { product innovative firms } \\
\text { by industry, region and size }\end{array}$} & & $0.011^{*}$ & & & 0.01 & \\
\hline & & $(0.006)$ & & & $(0.006)$ & \\
\hline \multirow{2}{*}{$\begin{array}{l}\% \text { process innovative firms } \\
\text { by industry, region and size }\end{array}$} & & & 0.01 & & & 0.0 \\
\hline & & & $(0.004)$ & & & $(0.004)$ \\
\hline Industry Dummies & Yes & Yes & Yes & Yes & Yes & Yes \\
\hline Region Dummies & Yes & Yes & Yes & Yes & Yes & Yes \\
\hline Observations & 1396 & 1396 & 1396 & 1396 & 1396 & 1396 \\
\hline Adjusted R-squared & 0.48 & 0.48 & 0.48 & 0.47 & 0.47 & 0.47 \\
\hline F-statistic & 57.72 & 57.56 & 57.67 & 57.60 & 57.40 & 57.56 \\
\hline
\end{tabular}

Notes: Robust standard errors in parentheses. The dependent variable is the firm's value added $(\log )$.

* significant at $10 \%$; ** significant at 5\%; *** significant at $1 \%$. 